\title{
Metaplastic carcinoma of the breast - A case study and review of literature
}

\author{
Manoj Kumar \\ Department of General Surgery, AIIMS, Patna, Bihar, India
}

\section{Introduction}

Metaplastic carcinoma is a rare but heterogeneous group of neoplasm of breast. Its variant includes low to high grade neoplasm. Spindle cell neoplasm is aggressive tumour associated with poor survival. Because of its rarity there is no standardized treatment guideline.

\section{Case Presentation}

We report the case of a 24 -year-old lady presented to our OPD with ulcerated lump in her left breast. She had no history of breast cancer in her first-degree relative. She had a history of painless lump in her left breast for the last 6 months, for which she consulted a homeopathic physician who started her on homeopathic medication. The lump gradually increased in size over the next few months and subsequently ulcerated 1 month back, with slough and intermittent bouts of bloody discharge.

The initial physical examination revealed a hard-lump measuring $10 \times 7 \mathrm{~cm}$ involving all quadrants of her left breast, with overlying ulceration with everted edges with foul smelling discharge, not fixed to the chest wall. Nipple not inverted. No palpable Axillary and supraclavicular lymph nodes present. No palpable lump in contralateral breast and axilla (Figure 1).

Ultrasonography described it as a large heterogeneously echogenic mass involving all quadrants of the breast with posterior acoustic shadowing with increased vascularity and dilated ducts extending from mass to nipple. The lesion was classified as Breast Imaging Reporting and Data System (BI-RADS) 5. USG also revealed presence of few enlarged lymph nodes with thickened cortex, some showing loss of fatty hilum, likely metastatic.

Open biopsy from ulcer margin was taken and sent for histopathological examination which revealed predominantly oval to spindle shaped cells arranged in diffuse sheet. These cells showed oval to spindle hyperchromatic nucleus, conspicuous to prominent eosinophilic nucleoli with abundant amount of cytoplasm. Few tumour giant cells were also seen. The Immunohistochemical (IHC) analysis showed a strong and diffuse positive reaction for Vimentin and SMA and a moderate positive reaction for Pan CK. Her-2neu, p40, ER and S-100 were negative. The conclusion of the pathology report was in favour of malignant spindle cell lesion favouring metaplastic carcinoma (Figure 2). USG guided FNAC from axillary lymph node showed presence of metastatic deposits. Metastatic work up for chest, abdomen and spine were performed and found negative for it. Mastectomy with axillary dissection was planned in view of metastatic deposits in the axilla, part of pectoralis major dissected as tumor was infiltrating the muscle. Subsequently LD flap reconstruction of chest

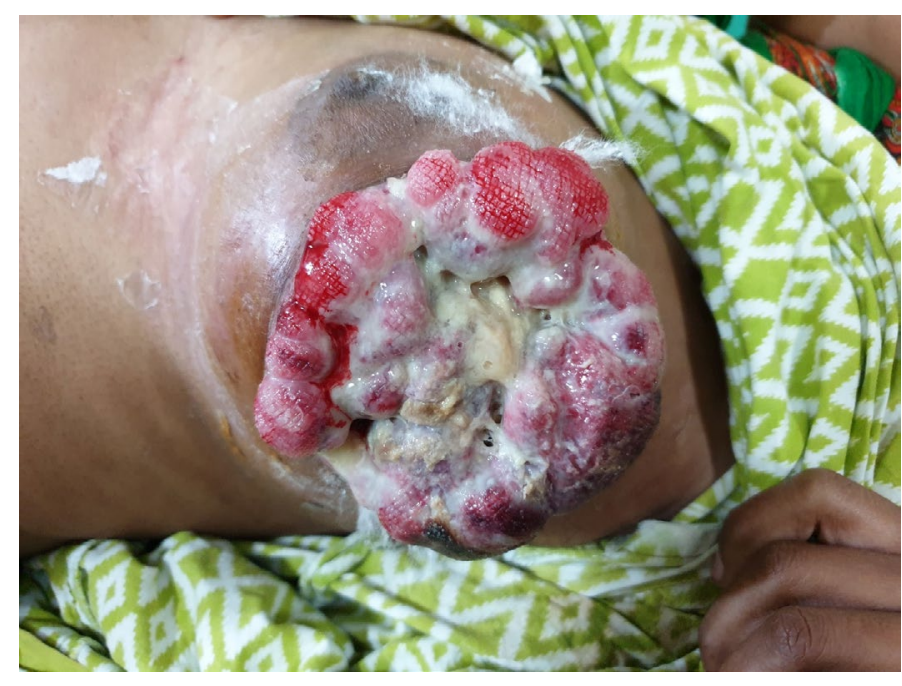

Figure 1. At initial Presentation

wall done (Figures 3-5). Post-operative period was uneventful. Patient later sent for adjuvant chemo and radiotherapy.

\section{Discussion}

Spindle cell metaplastic carcinoma is a variant of metaplastic carcinoma with predominance of spindle cells [1,2]. Metaplastic carcinoma of the breast is a heterogeneous group of rare neoplasm and it includes tumour with mixed carcinomatous and sarcomatoid (biphasic), or with sarcomatoid component alone (monophasic) $[3,4]$. While Wargotz et al. described metaplastic carcinoma into matrix-producing carcinoma, squamous cell carcinoma, spindle cell carcinoma, carcinosarcoma, and metaplastic carcinoma with osteoclastic giant cells [14-17].

The WHO Classification of Tumours of the Breast, 4th edition classifies metaplastic tumours into Metaplastic carcinoma of no special type, Low-grade adenosquamous carcinoma, Fibromatosislike metaplastic carcinoma, Squamous cell carcinoma, Spindle cell carcinoma, Metaplastic carcinoma with mesenchymal (Chondroid,

${ }^{*}$ Correspondence to: Manoj Kumar, Department of General Surgery, AIIMS, Patna, Bihar, India, Tel: 91-7321805753, E-mail: drmanojk@aiimspatna.org

Key words: spindle cell neoplasm, metaplastic carcinoma, sarcoma

Received: February 14, 2020; Accepted: February 24, 2020; Published: February 26,2020 


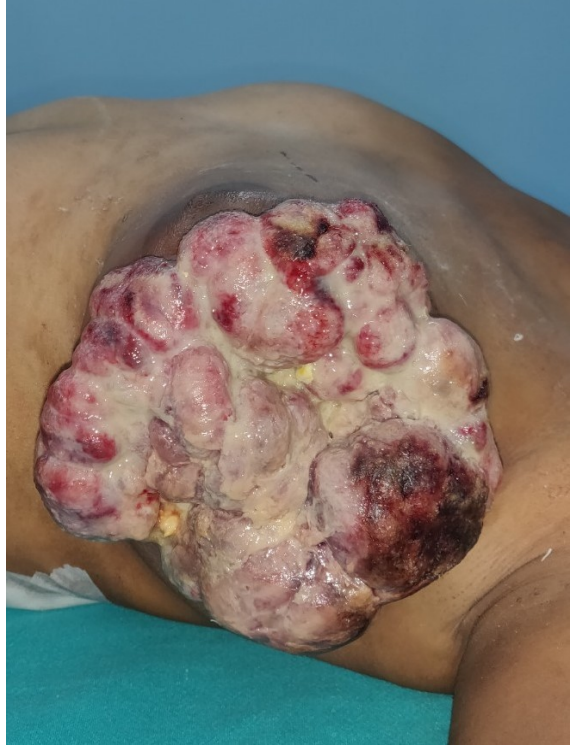

Figure 2. Immediate per-op picture 2 week after initial presentation

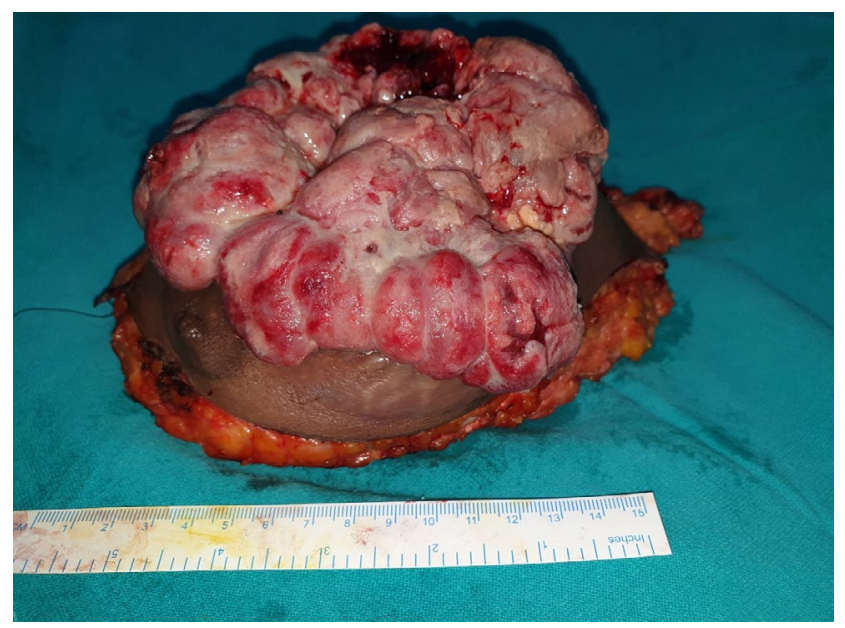

Figure 3. Excised ulcerated breast lump following MRM

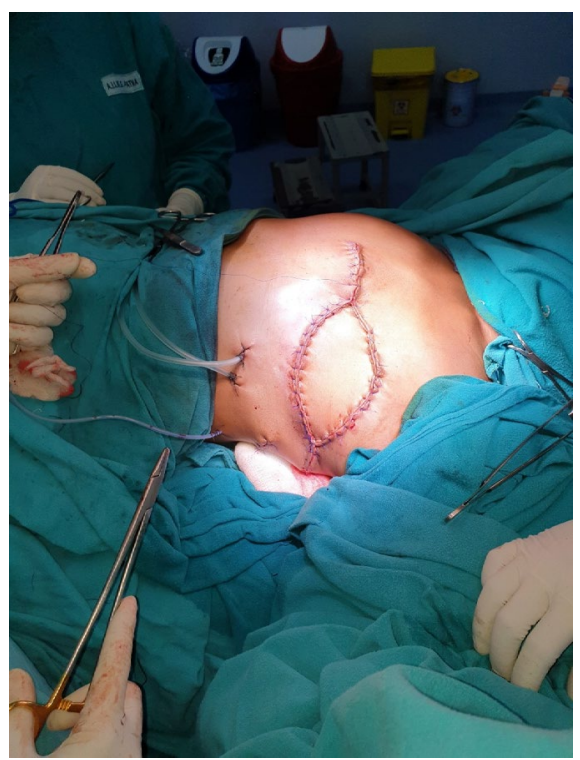

Figure 4. Appearance of the chest wall following LD Flap reconstruction
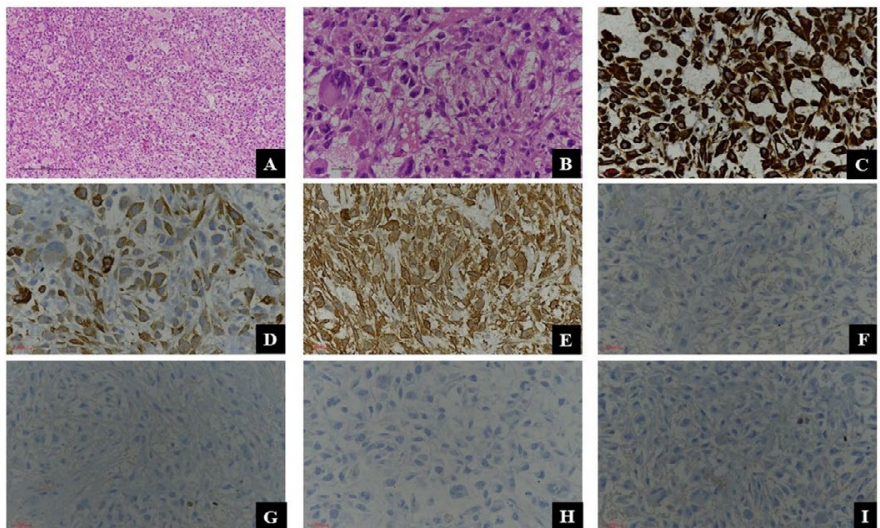

Figure 5. A. Round to oval to spindle shaped cells arranged in diffuse sheet. (H\&E x100) B. Oval to spindle shaped hyperchromatic nucleus, conspicuous to prominent eosinophilic nucleoli with abundant amount of cytoplasm, atypical mitosis and occasional gian cells. (H\&E x400) C. Strong and diffuse positive immunoreactivity for Vimentin. (IHC x400) D. Moderate and diffuse immunoreactivity for Pan CK. (IHC x400) E. Strong and diffuse positive immunoreactivity for SMA. (IHC x400) F. Negativity immunoreactivity for ER. (IHC x400) G. Negativity immunoreactivity for Her2Neu. (IHC x400) H. Negativity immunoreactivity for S100. (IHC x 400) I. Negativity immunoreactivity for P40. (IHC x400)

Osseous) differentiation, Other types of mesenchymal differentiation (Mixed), Myoepithelial carcinoma [5]. Metaplastic carcinomas may be either low-grade tumours (e.g. adenosquamous carcinoma or spindle cell carcinoma), or high-grade tumours (e.g. squamous cell carcinoma, or spindle cell carcinoma). [6]

Its presentation is similar to another breast cancer clinically as well as imaging/radiologically. Carter et al. reported age of presentation of tumour from 40 to 96 years with median of 68 years while 22 to 91 years by Luini $[7,8]$. Tumour size ranged from 1.5 to $15 \mathrm{~cm}$ with median of $4 \mathrm{~cm}$ in a series of 29 cases [7]. The tumour size in another series of 24 cases reported by Tse et al. ranged from $1.3 \mathrm{~cm}$ to $11.5 \mathrm{~cm}$ with a mean of $4.6 \mathrm{~cm}[4]$.

The reported incidence of axillary lymph node metastasis at diagnosis was $5 \%$ to $56 \%[4,7,9]$. Most common sites of distant metastasis are lung and bone [7]. These variations in the lymph node metastasis can be due to extent of the epithelial component and differentiation in the primary tumour [10]. In primary breast sarcoma lymph node metastasis is rare if present the diagnosis of a metaplastic carcinoma should be considered even in the presence of a pure spindle cell neoplasm [11].

\section{Immunohistochemistry (IHC)}

IHC plays a crucial role in the establishing accurate diagnosis of metaplastic carcinoma. It usually stains positive for Vimentin, SMA and pan- keratin and negative for ER/PR, HER2/Neu as similarly observed in the present case $[4,7,8,10]$.

\section{Treatment modality}

The optimal treatment modality for metaplastic carcinoma are not established because of its rarity and heterogeneity [22]. Commonly it is being treated similar to typical adenocarcinoma of the breast [12].

Treatment is by mastectomy or wide local excision with or without axillary node dissection combined with radiation with or without chemotherapy in most series [7,8]. The absence of hormone receptor and HER2/Neu limits the role of conventional chemotherapy and targeted therapy [10]. Post-lumpectomy radiotherapy was associated with higher overall survival in both the early and advance stage, while 
post-mastectomy radiotherapy was associated with overall survival benefits in advance stage, but not in early stage [23].In a retrospective study Tseng et al. suggested that radiotherapy should be considered a part of the multimodality therapy for patients with metaplastic carcinoma following surgery [12]. Leibl and Moinfar in his study of metaplastic carcinoma has shown that it frequently expresses EGFR than typical breast carcinoma and suggested that protein kinase inhibitors, such as gefitinib might be beneficial in the treatment of this aggressive tumour [13].

\section{5-year survival}

The cumulative 5-year survival rate for Spindle cell carcinoma, Carcinosarcoma, Squamous cell carcinoma and Metaplastic carcinoma with osteoclastic giant cells of $64 \%, 49 \%, 63 \%$ and $68 \%$ respectively [14-17]. Metaplastic carcinomas have a worse disease-free and overall survival when compared with adenocarcinoma $[8,21]$.

\section{Prognostic factors for survival}

In a study Chao et al. concluded that duration of symptoms, TNM stage, tumour size, and axillary nodal status were significant prognostic factors of survival [18]. Disease free survival and overall survival is less in metaplastic carcinoma as compared to invasive ductal carcinoma of the breast and other forms of triple-negative breast cancers $[19,20]$.

\section{Conclusion}

Rarity along and poor prognosis associated metaplastic carcinoma requires high degree of suspicion while investigating a breast lump with rapid growth. As there is no specific treatment guideline at present for metaplastic carcinoma review of literature suggests it should be treated like other invasive ductal carcinoma. As it is less responsive to conventional chemotherapy role of targeted therapy which is being evaluated in many studies may be beneficial to patient in near future.

\section{Learning points}

- Patient with rapid growth of breast mass should be evaluated keeping in mind the metaplastic or sarcomatoid neoplasm.

- Poor prognosis associated with these tumour requires urgent evaluation and treatment.

Alternative form of treatment for breast lump may be the cause for delayed and advance presentation.

\section{References}

1. Al-Nafussi A (1999) Spindle cell tumours of the breast: practical approach to diagnosis. Histopathology 35: 1-13. [Crossref]

2. Tay TKY, Tan PH (2017) Spindle cell lesions of the breast - An approach to diagnosis. Semin Diagn Pathol 34: 400-409. [Crossref]

3. Tse GM, Tan PH, Lui PC, Putti TC (2008) Spindle cell lesions of the breast--the pathologic differential diagnosis. Breast Cancer Res Treat 109: 199-207. [Crossref]
4. Tse GM, Tan PH, Putti TC, Lui PC, Chaiwun B, et al. (2006) Metaplastic carcinoma of the breast: a clinicopathological review. J Clin Pathol 59: 1079-1083. [Crossref]

5. Lakhani SR, Ellis IO, Shnitt SJ, et al. WHO classification of tumours. Vol. 4: WHO classification of tumours of the breast. 4th ed. Lyon: IARC Press; 2012.

6. Sinn HP, Kreipe H: A Brief Overview of the WHO Classification of Breast Tumors, 4th Edition, Focusing on Issues and Updates from the 3rd Edition. Breast Care 2013; 8: 149-154. doi: 10.1159/000350774

7. Carter MR, Hornick JL, Lester S, Fletcher CD (2006) Spindle cell (sarcomatoid) carcinoma of the breast: a clinicopathologic and immunohistochemical analysis of 29 cases. Am J Surg Pathol 30: 300-309. [Crossref]

8. Luini A, Aguilar M, Gatti G, Fasani R, Botteri E, et al. (2007) Metaplastic carcinoma of the breast, an unusual disease with worse prognosis: the experience of the European Institute of Oncology and review of the literature. Breast Cancer Res Treat 101: 349353. [Crossref]

9. Khan HN, Wyld L, Dunne B, Lee AH, Pinder SE, et al. (2003) Spindle cell carcinoma of the breast: a case series of a rare histological subtype. Eur J Surg Oncol 29: 600-603. [Crossref]

10. Lee AH (2008) Recent developments in the histological diagnosis of spindle cell carcinoma, fibromatosis and phyllodes tumour of the breast. Histopathology 52: 45-57. [Crossref]

11. Adem C, Reynolds C, Ingle JN, Nascimento AG (2004) Primary breast sarcoma: clinicopatholgic series from the Mayo Clinic and review of the literature. Br J Cancer 91: 237-241.

12. Tseng WH, Martinez SR (2011) Metaplastic breast cancer: to radiate or not to radiate? Ann Surg Oncol 18: 94-103. [Crossref]

13. Leibl S, Moinfar F (2005) Metaplastic breast carcinomas are negative for Her-2 but frequently express EGFR (Her-1): potential relevance to adjuvant treatment with EGFR tyrosine kinase inhibitors? J Clin Pathol 58: 700-704. [Crossref]

14. Wargotz ES, Deos PH, Norris HJ (1989) Metaplastic carcinomas of the breast. II. Spindle cell carcinoma. Hum Pathol 20: 732-740. [Crossref]

15. Wargotz ES, Norris HJ (1989) Metaplastic carcinomas of the breast. III Carcinosarcoma. Cancer 64: 1490-1499. [Crossref]

16. Wargotz ES, Norris HJ (1990) Metaplastic carcinomas of the breast. IV. Squamous cell carcinoma of ductal origin. Cancer 65: 272-276. [Crossref]

17. Wargotz ES, Norris HJ (1990) Metaplasic Carcinoma of the breast: V. Metaplasic carcinoma of the breast: metaplasic carcinoma with osteoclastic giant cell. Hum Pathol 21:1142-1150. [Crossref]

18. Chao TC, Wang CS, Chen SC, Chen MF (1999) Metaplastic carcinomas of the breast. $J$ Surg Oncol 71: 220-225. [Crossref]

19. Rayson D, Adjei AA, Suman VJ, Wold LE, Ingle JN (1999) Metaplastic breast cancer: prognosis and response to systemic therapy. Ann Oncol 10: 413-419. [Crossref]

20. Lee H, Jung SY, Ro JY, Kwon Y, Sohn JH, et al. (2012) Metaplastic breast cancer: Clinicopathological features and its prognosis. J Clin Pathol 65: 441-446. [Crossref]

21. Drekolias D, Mamounas EP (2019) Metaplastic breast carcinoma: Current therapeutic approaches and novel targeted therapies. Breast J 25: 1192-1197. [Crossref]

22. Tzanninis IG, Kotteas EA, Ntanasis-Stathopoulos I, Kontogianni P, Fotopoulos G (2016) Management and Outcomes in Metaplastic Breast Cancer. Clin Breast Cancer 16: 437-443. [Crossref]

23. Haque W, Verma V, Naik N, Butler EB, Teh BS (2018) Metaplastic Breast Cancer: Practice Patterns, Outcomes, and the Role of Radiotherapy. Ann Surg Oncol 25: 928 936. [Crossref]

Copyright: (C2020 Kumar M. This is an open-access article distributed under the terms of the Creative Commons Attribution License, which permits unrestricted use, distribution, and reproduction in any medium, provided the original author and source are credited. 